\title{
Корекція негативних психічних станів студентів засобами оздоровчого фітнесу
}

\author{
Ірина Іванишин ${ }^{1}$, Сергій Курилюк', \\ Василь Хлопецький ${ }^{1}$, Олег Вінтоняк²
}

1 Прикарпатський національний університет імені Василя Стефраника,

Івано-Франківськ, Україна

2 Івано-Франківський національний технічний університет нафрти і газу, Івано-Франківськ, Україна

\begin{abstract}
Анотація. У статті розглянуто проблему корекції негативних психічних станів студенток засобами оздоровчого фітнесу. Мета. Науково обґрунтувати та розробити технологію корекції негативних психічних станів студенток засобами оздоровчого фітнесу. Методи. Теоретичний аналіз та узагальнення даних науково-методичної літератури, методика експрес-оцінки соматичного здоров'я за Г. Л. Апанасенком; педагогічне тестування з використанням батареї тестів К. Зухори; психодіагностичні методики.

Результати. На основі кластерного та фракторного аналізів виділено систему найбільш типових для студенток негативних психічних станів та встановлено взаємозв'язки між їхнім психічним і фрізичним компонентами. Науково обгрунтувано та розроблено технологію корекції негативних психічних станів студенток засобами оздоровчого фрітнесу та експериментально перевірено ефрективність цієї технології. Впровадження технології корекції негативних психічних станів сприяло суттєвому покращенню параметрів психічного стану студенток, а також показників соматичного здоров'я та фрізичної підготовленості. Доведено вищу ефективність занять оздоровчим фрітнесом порівняно з традиційною системою фрізичного виховання з профрілактики негативних психічних станів студенток. Ключові слова: заклади вищої освіти, негативні психічні стани, оздоровчий фрітнес, факультативні заняття, самостійна робота.
\end{abstract}

\section{Iryna Ivanyshyn, Serhii Kuryliuk, Vasyl Khlopetskyi, Oleh Vintoniak}

\section{CORRECTING NEGATIVE MENTAL STATES OF STUDENTS BY MEANS OF HEALTH-RELATED FITNESS}

Abstract. The article considers the problem of correcting negative mental states of female students by means of health-related fitness. Objective. Scientifically substantiate and develop the technology of correcting negative mental states of students by means of health-related fitness. Methods. Theoretical analysis and generalization of data of scientific and methodical literature, methods of express assessment of somatic health according to GL Apanasenko; pedagogical testing using a battery of tests by K. Zukhora; psychodiagnostic techniques. Results. Based on cluster and factor analyzes, the system of the most typical for students negative mental states is identified and the relationships between their mental and physical components are established. The technology of correcting negative mental states of students by means of health-related fitness has been scientifically substantiated and developed and the effectiveness of this technology has been experimentally tested. The introduction of technology for correcting negative mental states has significantly improved the parameters of the mental state of female students, as well as indices of physical health and physical fitness. The higher efficiency of health-related fitness classes in comparison with the traditional system of physical education for the prevention of negative mental states of female students has been proved.

Keywords: institutions of higher education, negative mental states, health-related fitness, optional classes, independent work.

Ivanyshyn I., Kuryliuk S., Khlopetskyi V., Vintoniak 0. Correcting negative mental states of students by means of health-related fitness. Theory and Methods of Physical education and sports. 2021; 1 : 30-36 DOI: $10.32652 /$ tmfvs.2021.1.30-36
Іванишин I, Курилюк С, Хлопецький В, Вінтоняк О. Корекція негативних психічних станів студентів засобами оздоровчого фрітнесу. Теорія і методика фрізичного виховання і спорту. 2021; 1 : 30-36

DOI: 10.32652/tmfvs.2021.1.30-36
Вступ. Модернізація освіти в Україні, інтенсифрікація навчальної діяльності, що характеризується високою інформаційною насиченістю інноваційними методами навчання, недостатньою руховою активністю, призводить до значних нервово-психічних перевантажень, погіршення психофізичного здоров'я $[2,7,20]$.

Проте дослідження багатьох учених [1, 8, 10, 18, 19] свідчать про позитивний вплив рухової активності на психоемоційний стан студентської молоді. Ряд досліджень присвячено проблемам використання різних засобів оздоровчої рухової активності у фрізичному вихованні студентів [4, 6, 9, 13, 24].

Незважаючи на значну кількість наукових досліджень 3 питань використання оздоровчого фрітнесу у фізичному вихованні студентів, можна констатувати, що всі вони були в руслі впливу цих технологій на фізичний стан, питання ж їх впливу на психічний стан студентської молоді залишається на сьогодні не висвітленим. Сказане визначає науковопрактичну актуальність порушеної проблеми.

Мета дослідження - науково обґрунтувати та розробити технологію корекції негативних психічних станів студенток засобами оздоровчого фотнесу.

Методи дослідження: теоретичні; емпіричні; психодіагностичні; педагогічне тестування; педагогічний експеримент; методи математичної статистики.

Результати дослідження та їх обговорення. До експерименту було залучено 95 студенток 3 виявленими негативними психічними станами, які на момент проходження тестів висловили бажання брати участь у дослідженні, а також належали до основної медичної групи за станом здоров'я. Із цих студенток було сформовано контрольну (КГ) (47 осіб) та експериментальну (ЕГ) (48 осіб) групи. Представлений контингент сту- 
дентів був задіяний у дослідженні добровільно, давши письмову згоду на участь у всіх етапах констатуючого та формуючого експериментів, а також на подальший аналіз й оприлюднення їхніх особистих даних під час розгляду та висвітлення результатів дослідження.

Студентки КГ займалися за програмою з фізичного виховання, затвердженою навчальною частиною ДВНЗ «Прикарпатський національний університет імені Василя Стефаника», студентки ЕГ - за запропонованою нами програмою корекції негативних психічних станів засобами оздоровчого фітнесу, інтегрованою в технологію.

Дослідження фрізичного здоров'я проводили за допомогою методики експрес-оцінки соматичного здоров'я за Г.Л. Апанасенком [3]; фрізичну підготовленість оцінювали за допомогою педагогічного тестування 3 використанням батареї тестів К. Зухори [17]; з метою визначення психічного стану студенток використовували психодіагностичні методики: опитувальники К. Роджерса-Р. Даймонда, САМОАЛ, методики Спілберга-Ханіна, Н. Холла, САН, С. В. Омельяненко, А. Зверькова й $Є$. Ейдмана, шкалу депресії В. Зунга [12].

У процесі обробки експериментальних даних було використано метод дескриптивного аналізу та перевірки гіпотез, факторний аналіз [23].

Статистичну обробку матеріалу проводили на персональному комп'ютері 3 використанням електронних таблиць MS Excel та пакета прикладних програм «SPSS Statistics 17.0».

Факторний аналіз психічного та фрізичного станів студенток 3 негативними психічними станами дозволив обрати параметри, які мали факторне навантаження не нижче 0,5, і дав можливість виділити сім факторів, які пояснюють 76,35 \% загальної дисперсії.

Фактор I (21,81 \%) зібрав усі показники, що описують соціальнопсихологічну адаптацію студенток: інтернальність ( $r=0,954)$, емоційний комфорт $(r=0,912)$, наполегливість $(r=0,869)$, прийняття інших $(r=0,869)$, адаптація $(r=0,863)$, самоприйняття $(r=0,860)$, професійний вибір ( $r=0,836)$ і самовладання $(r=0,823)$ - $з$ одного боку, а 3 іншого - реактивна тривожність $(r=-0,868)$, впевненість $(r=-0,768)$ й особистісна тривожність $(r=-0,595)$. Як бачимо, чим вищі рівні особистісної та реактивної тривожності, а також самовпевненості, тим нижча соціально-психологічна адаптація студенток.

Фактор II (16,84 \%) описує емоційний інтелект. До нього ввійшли самопочуття ( $r=0,909)$, активність $(r=0,900)$, настрій $(r=0,880)$, управління своїми емоціями ( $r=0,841)$, емпатія $(r=0,777)$, розпізнавання емоцій інших людей $(r=0,729)$, самомотивація $(r=0,727)$, а також вербальна агресія $(r=-0,676)$. Чим вищий рівень емоційного інтелекту особистості, тим нижчими є показники агресії та вищі показники самопочуття.

До уніполярного фактора III $(9,97 \%)$ увійшли показники емоційної нестабільності ( $r=0,879)$, почуття провини ( $r=0,810)$, негативізму $(r=0,770)$, образи $(r=0,764)$ та депресії $(r=0,557)$. Цей фрактор охарактеризуємо як депресивний стан.

До біполярного фактора IV $(8,10 \%)$ віднесено показники прагнення до самоактуалізації ( $r=0,840)$, жага до домінування $(r=0,785)$, вербальна агресія $(r=0,536)-3$ одного боку, та підозріливість $(r=-0,753)-3$ іншого. Таким чином, ми визначили цей фактор як самореалізація.

До біполярного фактора $\boldsymbol{V}$ $(7,07 \%)$ увійшли показники фрізичного здоров'я: індекс маси тіла $(r=0,924)$, силовий індекс $(r=0,879)$, життєвий індекс $(r=0,788)$ та адаптаційний потенціал Баєвського $(r=0,692)$. Отже, показники фрізичного здоров'я мають досить тісний кореляційний зв'язок з характеристиками психічного стану студенток.

До уніполярного фактора VI (6,74 \%) віднесено показники роздратованості ( $r=-0,709)$, фрізичної агресії ( $r=-0,648)$ та побічної агресії $(r=-0,552)$, які характеризують агресивність поведінки. Як бачимо, ці показники мають зворотний зв'язок із гармонійним психічним станом студенток.

До уніполярного фактора VII $(5,82 \%)$ увійшли всі показники фрізичної підготовленості студенток: витривалість ( $r=0,653)$, силова витривалість м'язів живота ( $r=0,642)$, швидкість $(r=0,641)$, швидкісна сила м'язів ніг ( $r=0,610)$, силові якості м'язів рук $(r=0,598)$ та гнучкість $(r=0,486)$. Слід відмітити прямий взаємозв'язок між показниками фрізичної підготовленості та психічного стану студенток.

Результати сракторного аналізу було враховано під час розробки технології корекції негативних психічних станів студенток засобами оздоровчого фрітнесу (рис. 1). Складовою технології була програма корекції негативних психічних станів засобами оздоровчого фітнесу, метою якої було розширення теоретичних знань студенток про психічні стани людини, їх негативні прояви; фрормування умінь контролю та управління власним психічним станом.

Комплексність розробленої програми корекції негативних психічних станів студенток засобами оздоровчого фрітнесу забезпечувалася поєднанням засобів оздоровчого фітнесу аеробної спрямованості, силової спрямованості, програм «ментального фрітнесу» (йога, китайська гімнастика у-шу, кунг-фу, оздоровча система Норбекова, Хвана, «шість правил здоров'я» К. Ніші, стретчинг, пілатес), корекційних комплексів фрізичних вправ, дихальної гімнастики, що реалізувалися через принципи варіативності і модульності, а також дидактичні принципи систематичності, послідовності, доступності, єдності діагностики і корекції, комплексного використання методів, корекційнопедагогічної діяльності, принцип інтеграції особистісних зусиль та соціального оточення.

Усі корекційні компоненти негативних психічних станів студенток, запропоновані у програмі, реалізувались у три етапи - інфрормаційномотивуючий, корекційно-поведінковий і особистісно-діяльнісний.

Реалізація змісту програми проходила у три етапи: інформаційно- 


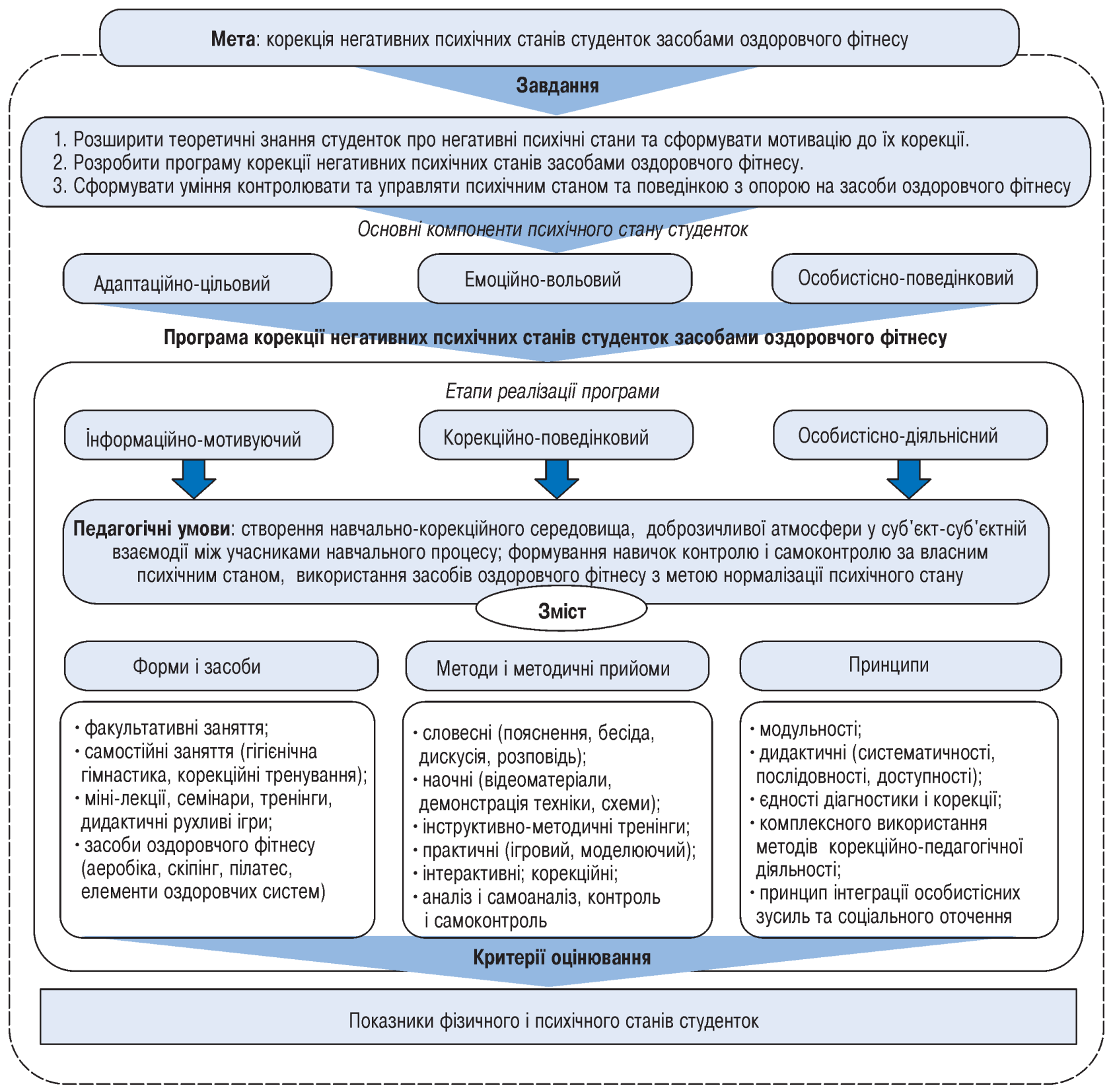

Рисунок 1 - Блок-схема технології корекції негативних психічних станів студенток засобами оздоровчого фітнесу

мотивуючий (20 год), корекційноповедінковий (160 год: 20 год - тематичні тренінги, 140 год - оздоровчий фрітнес); особистісно-діяльнісний (самостійні заняття - 280 год), що разом становило 460 год.

Критеріями оцінювання впливу занять оздоровчою гімнастикою на нормалізацію психічного стану студенток слугували методики визначення динаміки показників і рівнів психічного стану, фрізичної підготовленості та соматичного здоров'я.

у процесі повторного опитування студенток, які мали різного роду негативні психічні стани, спостеріга- лось суттєве покращення параметрів психічного стану осіб ЕГ порівняно 3 КГ: по-перше, стан тривоги знизився на 23,31\%, страху - на 23,31\%, агресії - на 6,66 \%, астенії - на 9,98\%; частка студенток ЕГ 3 низьким і високим рівнями агресивності зменшилася відповідно на 10,43 і 16,67 \% $(p<0,05)$; зменшилося на рівні статистичної тенденції середньогрупове значення показника фрізичної агресії порівняно як з вихідним значенням, так і порівняно з таким самим у КГ після експерименту ( $<<0,1)$; високим рівнем реактивної тривожності - на $12,50 \%(p<0,05)$, а також на рівні статистичної тенденції зменшилася на 20,83 \% частка дівчат ЕГ 3 високим рівнем особистісної тривожності ( $<<0,1)$; частка студенток ЕГ 3 високим рівнем самоконтролю наприкінці експерименту становила $12,50 \%$, тоді як до експерименту таких не було ( $p<0,01)$; в ЕГ статистично значуще зменшилася частка студенток з субдепресивним станом - на 16,66 \%, частка 3 відсутньою депресією наприкінці експерименту становила в ЕГ 43,75 \%, з легкою депресією ситуативного або невротичного ґенезу - 52,08 \% ( $p<0,01)$; наприкінці експерименту в ЕГ значення показ- 
ника самопочуття покращилось на $5,42$ бала ( $p<0,01)$, активності - на $5,47$ бала ( $p<0,05)$, а настрою - на $4,77$ бала ( $p<0,01)$. Слід відмітити статистично значущі відмінності між показниками студенток ЕГ і КГ після експерименту за такими субшкалами: орієнтація в часі $(p<0,01)$, погляд на природу людини $(p<0,05)$, потреба в пізнанні $(p<0,01)$, автономність $(p<0,05)$, аутосимпатія $(p<0,01)$, контактність $(p<0,05)$ і гнучкість у спілкуванні $(p<0,05)$. Це вказує на вищу ефективність занять оздоровчим фрітнесом порівняно з традиційною системою фрізичного виховання у профрілактиці негативних психічних станів студенток.

Як показав аналіз результатів повторного вимірювання, статистично значущі $(p<0,05)$ відмінності середньогрупових значень показників морфоффункціонального стану наприкінці експерименту у студенток ЕГ спостерігалися для всіх показників, за винятком антропометричних (довжина тіла, маса тіла, індекс маси тіла), а також систолічного і діастолічного артеріального тиску (табл. 1). За ними не було отримано статистично значущої різниці, хоча була виражена тенденція до позитивної динаміки.

Найбільших змін у ЕГ зазнали такі показники, як частота серцевих скорочень (ЧСС), кистьова динамометрія та життєва ємність легень (ЖЕЛ) i, як наслідок, показники силового індексу (CI), життєвого індексу (ЖІ) та індексу Робінсона. Це позитивно позначилося на стані фрізичної підготовленості студенток.

У результаті у студенток ЕГ суттєво покращився інтегральний показник фізичної підготовленості. Мінімальний рівень фрізичної підготовленості мали 2,08 \% дівчат проти $27,08 \%$ до експерименту, задовільний - 52,08 \% проти 54,17 \%, добрий та дуже добрий рівні фрізичної підготовленості мали $39,58 \%$ та 4,17\% відповідно (рис. 2). Слід зазначити, що у 2,08 \% студенток виявлено ви- сокий рівень фрізичної підготовленості, чого не спостерігалося до експерименту $(p<0,01)$.

Аналіз динаміки рівнів фрізичної підготовленості студенток КГ виявив незначне зростання рівня фрізичної підготовленості - збільшення частки осіб із задовільним і добрим рівнями за рахунок зменшення частки із мінімальним.

Дискусія. Як зазначено в наукових роботах [2, 7, 22], адаптація студенток до нових незвичних умов закладів вищої освіти (ЗВ0) залежить як від фізичного, так і психічного здоров'я особистості. Різка зміна усталеного роками психомоторного стереотипу діяльності часто призводить до стресів і нервових зривів [10, 11].

Наші дані узгоджуються з даними ряду науковців про те, що протягом навчання у ЗВО показники фізичного здоров'я студенток знижуються [1, 3]. Відсутність активної м'язової роботи забирає велику кількість вну-

Т а б л и ц я 1. Динаміка значень показників складових соматичного здоров'я студенток з негативними психічними станами за час формувального експерименту, $\mathrm{x} \pm \mathrm{S}$

\begin{tabular}{|c|c|c|c|c|}
\hline \multirow{2}{*}{ Показники } & \multicolumn{2}{|c|}{ До експерименту } & \multicolumn{2}{|c|}{ Після експерименту } \\
\hline & КГ $(n=47)$ & $\mathrm{E} \Gamma(n=48)$ & $\mathrm{K \Gamma}(\mathrm{n}=47)$ & EГ $(n=48)$ \\
\hline Довжина тіла, см & $168,06 \pm 3,88$ & $166,21 \pm 3,99$ & $168,61 \pm 3,65$ & $166,89 \pm 3,78$ \\
\hline Маса тіла, кг & $60,51 \pm 9,27$ & $57,45 \pm 7,33$ & $60,47 \pm 8,21$ & $57,36 \pm 5,54 \times$ \\
\hline їндекс маси тіла, кг · м-2 & $21,40 \pm 2,94$ & $20,80 \pm 2,61$ & $21,24 \pm 2,49$ & $20,59 \pm 1,81$ \\
\hline АТсист, мм рт. ст. & $120,94 \pm 8,55$ & $121,00 \pm 7,31$ & $116,98 \pm 11,15$ & $121,17 \pm 5,42^{x}$ \\
\hline АТдіаст, мм рт. ст. & $65,38 \pm 4,86$ & $64,65 \pm 5,50$ & $65,26 \pm 4,71$ & $64,33 \pm 5,53$ \\
\hline ЧСС, уд $\cdot$ хв$^{-1}$ & $74,38 \pm 4,78$ & $74,71 \pm 4,75$ & $74,66 \pm 3,43$ & $70,38 \pm 3,52^{* *_{x}}$ \\
\hline Їндекс Робінсона, ум. од. & $89,89 \pm 8,03$ & $90,36 \pm 7,59$ & $87,26 \pm 8,69^{\bullet}$ & $85,27 \pm 5,77^{\star}$ \\
\hline ЖЕЛ, мл & $2340,43 \pm 397,09$ & $2293,75 \pm 385,59$ & $2317,02 \pm 375,51$ & $2475,00 \pm 316,37^{*_{x}}$ \\
\hline Жі, мл $\cdot \mathrm{k}^{-1}$ & $39,51 \pm 8,59$ & $40,54 \pm 7,98$ & $38,79 \pm 7,98$ & $43,46 \pm 6,38^{* \times}$ \\
\hline Динамометрія правої кисті, кГ & $23,11 \pm 2,29$ & $23,10 \pm 2,15$ & $22,06 \pm 1,72^{\bullet}$ & $25,44 \pm 2,19^{* *_{x x}}$ \\
\hline Динамометрія лівої кисті, кГ & $20,96 \pm 1,97$ & $21,19 \pm 2,18$ & $19,77 \pm 1,51^{\bullet}$ & $22,44 \pm 2,21^{* *_{x \times}}$ \\
\hline Ci, \% & $39,03 \pm 7,20$ & $41,05 \pm 7,20$ & $37,11 \pm 5,63$ & $44,78 \pm 6,00^{* \times x}$ \\
\hline $\begin{array}{l}\text { Час відновлення після } 20 \\
\text { присідань за } 30 \text { с, с }\end{array}$ & $97,02 \pm 27,24$ & $92,79 \pm 25,54$ & $87,02 \pm 25,23$ & $63,50 \pm 19,63^{* *_{x x}}$ \\
\hline $\begin{array}{l}\text { Адаптаційний потенціал за } \\
\text { Р. Баєвським, ум. од. }\end{array}$ & $2,03 \pm 0,16$ & $2,01 \pm 0,14$ & $1,98 \pm 0,19$ & $1,97 \pm 0,11$ \\
\hline РСЗ (Апанасенко), ум. од. & $2,51 \pm 0,47$ & $3,54 \pm 0,34$ & $3,43 \pm 0,36$ & $7,21 \pm 0,33^{*_{x \times}}$ \\
\hline
\end{tabular}

Примітки: статистично значущі відмінності показників студенток до та після експерименту: ЕГ: * $-p<0,05$;

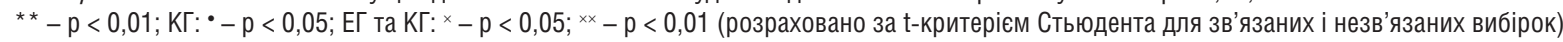




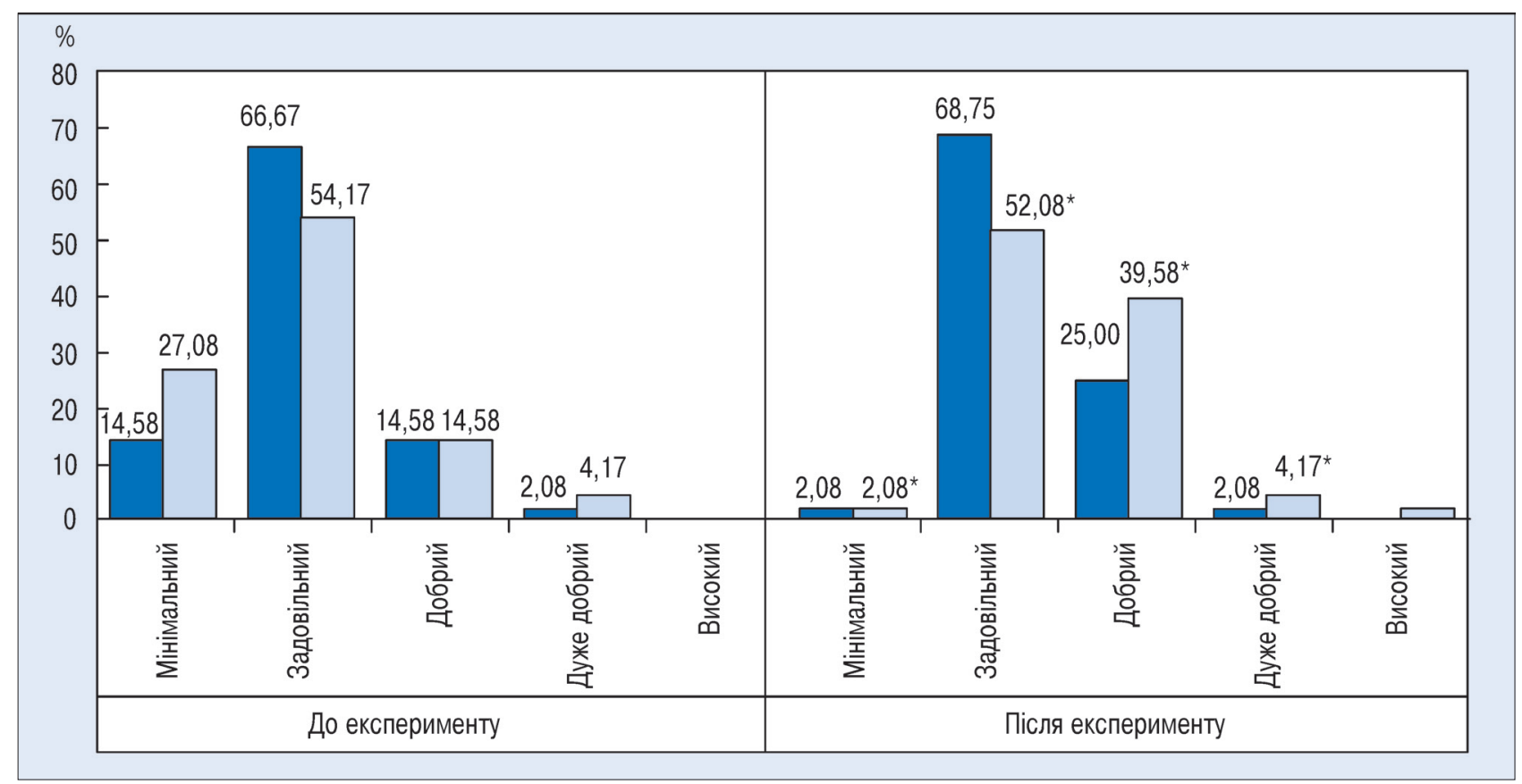

Рисунок 2 - Динаміка розподілу студенток за рівнем фрізичної підготовленості за час формуючого експерименту, \%: * - статистично значущі відмінності у розподілі до та після експерименту за критерієм $\chi^{2}$-Пірсона $(\mathrm{p}<0,01)$; $\square$ - КГ $(\mathrm{n}=47)$; $\square-\mathrm{E \Gamma}(\mathrm{n}=48)$

трішньої енергії та знижує впевненість у своїх силах [19].

Іншою причиною такої ситуації $€$ нераціональний спосіб життя (несвоєчасний і нерегулярний режим харчування, сну, недостатнє знаходження на свіжому повітрі, низька рухова активність (РА), відсутність загартувальних процедур, виконання навчальних завдань уночі, шкідливі звички тощо), притаманний студенткам, що підтверджує дослідження деяких учених [2]. Негативні наслідки нераціональної організації життєдіяльності проявляються нестійкістю настрою, погіршенням самовладання, станом апатії, підвищеною стомлюваністю, зниженням психічної активності $[2,16]$.

Отримані нами дані доповнюють дослідження $[11,16]$ про негативні психічні стани студенток. Так, згідно 3 результатами досліджень [11], загальна кількість студенток із негативними психічними станами становить $82,56 \%$, а за нашими даними - від 32 \% до 80 \% залежно від типу комплексів негативних психічних станів. Нами підтверджено також дані досліджень [7, 11], в яких виявлено, що серед студенток найбільш поширеними проявами негативних психічних станів є низький рівень емоційної обізнаності $(64,73 \%)$, управління своїми емоціями (70,54 \%), 79,46 \% студенток зазнають труднощів в оцінюванні та диференціації емоційних станів інших. Таким чином, ми прийшли до висновку, що студенткам необхідно підвищувати свій рівень емоційного інтелекту для уникнення труднощів, пов'язаних із соціальною адаптацією й академічною успішністю.

Наступними за поширеністю стали такі прояви негативних психічних станів, як агресивність (69,38 \%), що корелювало 3 деякими дослідженнями [14], де відсоток студенток 3 показником спонтанної агресивності становив 55,9\%, а реактивної агресивності - 72,3\%.

За рівнями реактивної й особистісної тривожності відповідно $35,27 \%$ та 21,91 \% студенток мали високий рівень, тобто вони схильні до постійної тривоги, спричинити яку могли не тільки ставлення до навчання, а й різні життєві ситуації. Ці дані практично ідентичні з результатами досліджень [16], де кількість студенток $з$ високим показником тривожності становила у середньому від 29 \% на першому курсі до $20 \%$ на третьому.

Приблизно така сама картина спостерігалася і для показника депресії. У нашому випадку субдепресивний стан або стан маскованої де- пресії мали 8,91 \% студенток, а легкої депресії ситуативного або невротичного генезу - 32,95 \%, тобто 41,86 \% дівчат мали той чи інший прояв депресивності. За даними одних досліджень [14], кількість осіб з депресивними станами становила 54,35 \%, а за даними інших [20] - депресія спостерігалася в 38 \% студенток.

Аналіз отриманих результатів за методикою САН засвідчив, що середне арисметичне показників самопочуття, активності й настрою студенток, котрі взяли участь у дослідженні, відповідало середній та високій оцінкам за шкалами «самопочуття» та «активність» і тільки 1,16 \% усіх дівчат мали поганий настрій, що не узгоджується 3 результатми дослідження [14], де незадовільне самопочуття мали до 32 \% студенток, поганий настрій - $30 \%$, слабко виражену активність - 38 \%. Проте ці дані узгоджуються 3 результатами дослідження [16], де самопочуття, активність та настрій студенток 15-17 років оцінили середніми й високими балами, при цьому рівень активності всіх представниць був достовірно меншим за показники самопочуття та настрою.

у $36,43 \%$ студенток показник прагнення до самоактуалізації як інтегральної характеристики розви- 
тку особистості перебував у межах норми, за нижньою межею опинились тільки 2,33 \% осіб і більшість $(61,24 \%)$ потрапили у так званий «діапазон самоактуалізації». Ці дані дещо суперечать результатам деяких досліджень [7], де за нижньою межею опинились 31,07 \% студенток.

Значний відсоток респондентів 3 низьким прагненням до самоактуалізації викликає занепокоєння, адже це говорить про неможливість молоді віднайти та проявити себе, про наявність ряду психологічних проблем і, за певних обставин, про схильність до психічних розладів. Необхідність витримувати тиск напруженого навчання, долати складні життєві ситуації, гармонійно існувати у швидкому та насиченому темпі інформаційного суспільства вимагає від особистості відповідної психологічної готовності. Інакше виникає внутрішній дисбаланс, який має ряд зовнішніх проявів: на фоні загальної дезадаптації спостерігається надмірна тривожність, невпевненість у собі, залежність від обставин, схильність до афективних проявів тощо.

На думку деяких учених [2, 5, 14, 18], активна фрізична діяльність має дуже важливе значення для психічних процесів людини. Проблема вузівської психогігієни полягає в тому, що необхідно враховувати не тільки вік, специфіку навчального процесу, а й постійно дбати про психічне здоров'я студенток, ліквідацію дискомфорту, надмірної тривожності, що породжує невпевненість, а, часом і страх, про створення здорового, оптимістичного психічного настрою [22].

Спортивно-оздоровча система фрітнес - це досить розгалужене середовище 3 великою кількістю різноманітних фрітнес-програм, що базуються як на фрізичному впливі, так і на ментальних засобах фрітнесу (медитація, дихальні вправи). Актуальність дослідження впливу засобів оздоровчого фрітнесу на психічний стан підтверджує той фракт, що ще сторіччя тому І. М. Сєченов і П. Ф. Лесгафрт [15] вказували на важливість наукової розробки та розвитку психомоторних здібностей людини як єдності їі фрізичної та психічної сcpep.
Незважаючи на численні дослідження, актуальним залишається питання впровадження сучасних оздоровчих технологій (як на фрізичному, так і ментальному рівнях) у навчальний процес 3ВО [5, 8, 9, 21].

Технологію корекції негативних психічних станів студенток засобами оздоровчого фрітнесу ми розробляли, виходячи з того, що, по-перше, існує тісний взаємозв'язок між психічним та фрізичним станами людини [19, 21], по-друге, як показав аналіз досліджень ряду науковців [9, 15, 17, 19], найбільш затребуваними та популярними є фітнес-програми аеробної, силової та ментальної спрямованості.

Як зазначають учені [10], через розвиток пластичності в тілі стабілізується емоційна врівноваженість, зменшується агресивність, відбувається розвиток вольових якостей людини, таких як цілеспрямованість, рішучість, наполегливість, самовладання, самостійність та ініціативність, розвиваються стійкість до стресів, уміння управляти емоціями й рухами, здатність сприймати, аналізувати й реагувати на інформацію в умовах десріциту часу та простору.

Таким чином, реалізовані в ході формуючого експерименту заняття оздоровчим фітнесом у поєднанні 3 ментальним фотнесом $€$ спонукальною, спрямовуючою та регулюючою силою, яка регламентує поведінку студенток на цих заняттях.

Висновки. Проведені дослідження свідчать про позитивний вплив технології корекції негативних психічних станів студенток засобами оздоровчого фрітнесу на показники їхніх психічного та фрізичного станів. Отримані результати дають підстави рекомендувати розроблену технологію корекції негативних психічних станів студенток 3 використанням оздоровчого фрітнесу для навчально-виховного процесу з фрізичного виховання студенток 3В0.

Перспективи подальших досліджень передбачають впровадження технології корекції негативних психічних станів студентів засобами оздоровчого фрітнесу у навчальновиховний процес з фрізичного виховання 3В0 різних рівнів.
Конфлікт інтересів. Автори заявляють, що відсутній будь-який конфллікт інтересів.

\section{ЛITEPATУРА}

1. Андрєєва 0, Садовський 0. Рухова активність як складова рекреаційної культури студентів. Теорія і методика фрізичного виховання і спорту. 2016;1:19-22. DOI: https:doi. org/10.32652/tmfvs.2016.1.19-22.

2. Анікєєв ДМ. Рухова активність у способі життя студентської молоді. [автореферат] Національний університет фізичного виховання і спорту України. 2012. 20 с.

3. Апанасенко ГЛ. Индивидуальное здоровье: теория и практика. Введение в теорию индивидуального здоровья. Киев: Медкнига; 2011. 108 c.

4. Баклицька 0, Сірко Р. Аналіз методів корекції психічного здоров'я студентсько молоді. Концепція розвитку галузі фрізичного виховання і спорту в Україні: зб. наук. пр 2006;4:82-87

5. Барибіна ЛМ. Індивідуалізація навчального процесу 3 фрізичного виховання у вищих навчальних закладах із урахуванням психофізіологічних можливостей студентів [дисертація]. Харків. 2013. 339 с.

6. Благій ОЛ, Лисакова НМ. Тенденції розвитку групових фітнес-програм. Теорія і мето дика фізичного виховання і спорту. 2013;2:5458.

7. Боднар І, Вовканич Л, Духта Т. Властивості нервової системи та психоемоційний стан студентів вищих навчальних закладів III-IV рівнів акредитації. Слобожанський науковоспортивний вісник. 2012;3:94-98.

8. Випасняк ІП. Корекційно-профілактичні технології у фрізичному вихованні студентів із функціональними порушеннями опорно-рухового апарату, практична складова автроської концепції. Вісник Східноєвропейського національного університету імен Лесі Українки. Фізичне виховання і спорт 2018;29:21-28

9. Жамардій В. Концептуальна модель застосування фітнес-технологій на заняттях із фізичного виховання студентів. Педагогічні науки: теорія, історія, інноваційні технології. 2018; 3(77):77-88. DOI: 10.24139/2312 5993/2018.03/077-088.

10. Іванишин ЮІ, Ковальчук ЛВ, Іванишин IM. Особливості психологічних характеристик підлітків 3 різним рівнем рухово активності і різною спортивною спеціалізацією. Науковий часопис Національного педагогічного університету імені М. П. Драгоманова. Серія 15: Науково-педагогічні проблеми фізичної культури / фрізична культура і спорт: зб. наук. праць 2017;5K(86):128-134

11. Ігумнова ОБ. Індивідуальні та особистісні властивості студентів 3 негативни ми психічними станами. Вісник Національної академії Державної прикордонної служби України. Доступно: http://nbuv.gov.ua/UJRN/ Vnadps_2012_5_38

12. Комінко СБ, Кучер ГВ. Кращі методи психодіагностики: навчальний посібник Тернопіль: Карт-бланш; 2005. 406 с.

13. Мартинова НП. Нові види аеробіки як засіб розвитку рухових якостей студенток вищих навчальних закладів. Слобожанський науково-спортивний весник. 2014;1(39):62-65. 
14. Пічурін ВВ. Особливості взаємозв'язку фізичної підготовленості і психофізичних характеристик у студентів. Науковий часопис. Серія: Науково-педагогічні проблеми фізичної культури. Фізична культура і спорт. 2017;3К(84)17:365-68.

15. Родин ЮИ. Проблема психомоторики человека в свете естественнонаучной парадигмы. Психология. Историко-критические обзорь и современные исследования. 2017;6(5A):5-23.

16. Семенова Н, Магльований А. Рухова активність та психоемоційний стан студенток 15-17 років. Physical education, sport and health culture in modern society. 2015;2(30):95-98.

17. Сергієнко ВМ. Теоретико-методологічн основи контролю рухових здібностей студентської молоді у процесі фрізичного виховання [автореферат]. Київ. 2016. 46 с.

18. Acevedo Edmund. Exercise Psychology: Understanding the Mental Health Benefits of Physical Activity and the Public Health Challenges of Inactivity. The Oxford Handbook of Exercise Psychology; 2012. DOI: 10.1093/oxford hb/9780195394313.013.0001.

19. Biddle S. Physical activity and mental health: evidence is growing. World Psychiatry 2016;15(2):176-77. DOI: 10.1002/wps.20331.

20. Grasdalsmoen M, Eriksen HR, Lønning KJ, Sivertsen B. Physical exercise, mental health problems, and suicide attempts in university students. BMC Psychiatry. 2020 Apr 16;20(1):175 DOI: 10.1186/s12888-020-02583-3.

21. Khlopetskyi V, Kuryliuk S. Correction of students negative states by health fitness means as a scientific problem. Journal of Education, Health and Sport. 2017. 7 (2):859-70. eISSN 2391-8306. DOl: http:.dx.doi.org/10.5281/zenodo.3879686.

22. Lubans D, Richards J, Hillman C, Faulkne G, Beauchamp M, Nilsson M. et al. Physical activity for cognitive and mental health in youth: a sys tematic review of mechanisms. Pediatrics. 2016 138(3): e20161642. DOI: 10.1542/peds.2016 1642.

23. Newell J, Aitchison T, Grant St. Statistics for Sports and Exercise Science: A Practi- cal Approach. 1st Edition. Routledge; 1st edition (October 7, 2009); $440 \mathrm{p}$.

24. Thompson W. Worldwide survey of fitness trends for 2019. ACSM's Health \& Fitness Journal. 2018;22:10-17. DOI: 10.1249/ FIT.0000000000000438.

\section{LITERATURE}

1. Andreieva 0, Sadovskyi 0. Motor activity as a constituent of student recreational culture. Teoriia i metodyka fizvykhovannia i sportu. 2016:1:19-22. DOl: https:doi.org/10.32652/tmfvs.2016.1.19-22.

2. Anikeiev DM. Motor activity in student youth way of life. [author's abstract]. National University of Physical Education \& Sport of Ukraine. 2012. $20 \mathrm{p}$.

3. Apanasenko HL. Individual health: theory and practice. Introduction in the individual health theory. Kiev: Medkniha; 2011. 108 p.

4. Baklytska 0, Sirko R. Analysis of methods for correcting students' mental health. Concept of physical education and sport branch development in Ukraine: zb. naukovykh prats. 2006;4:82-87.

5. Barybina LM. Individualization of the educational process in physical education in higher educational institutions taking into account the psychophysiological capabilities of students [dissertation]. Kharkiv. 2013. 339 p.

6. Blahii OL, Lysakova NM. Development trends of group fitness programs. Teoriia i metodyka fizvykhovannia i sportu. 2013;2:54-58.

7. Bodnar I, Vovkanych L, Dukhta T. Properties of the nervous system and psycho-emotional state of students of higher educational institutions of IIIIV levels of accreditation. Slobozhanskyi naukovosport. visnyk. 2012;3:94-98.

8. Vypasniak IP. Correctional and preventive technologies in physical education of students with functional disorders of the musculoskeleta system, the practical component of the author's concept. Visnyk Skhidnoievropeyskoho universytetu im. Lesi Ukrainky. 2018;29:21-28.

9. Zhamardii V. Conceptual model of application of fitness technologies in classes on physical

\section{ІНФОРМАЦІЯ ПРО АВТОРІВ}

Іванишин Ірина Мирославівна https://orcid.org/0000-0003-1765-8311, iraivan68@gmail.com Курилюк Сергій Іванович https://orcid.org/0000-0003-1588-5756, upa231@ukr.net Хлопецький Василь Михайлович https://orcid.org/0000-0002-9600-6866, upa231@ukr.net ДВНЗ «Прикарпатський національний університет імені Василя Стефаника», 76018, Івано-Франківськ, вул. Шевченка, 57

Вінтоняк Олег Васильович https://orcid.org/0000-0003-4940-1238, oleg.v@ukr.net Івано-Франківський національний технічний університет нафти і газу 76019, Івано-Франківськ, вул. Карпатська, 15

\section{INFORMATION ABOUT THE AUTHORS}

Ivanyshyn Iryna https://orcid.org/0000-0003-1765-8311, iraivan68@gmail Kuryliuk Serhii https://orcid.org/0000-0003-1588-5756, upa231@ukr.net Khlopetskii Vasyl https://orcid.org/0000-0002-9600-6866, upa231@ukr.net

Vasyl Stefanyk Precarpathian National University,

76018, Ivano-Frankivsk, Shevchenko str., 57

Vintoniak Oleg https://orcid.org/0000-0003-4940-1238, oleg.v@ukr.net Ivano-Frankivsk National Technical University of Oil and Gas 76019, Ivano-Frankivsk, Karpatska str., 15 education of students. Pedahohichni nauky: teoriia, istoriia, innovatsiyni tekhnolohii. 2018; 3(77):7788. DOI: 10.24139/2312-5993/2018.03/077-088.

10. Ivanyshyn II, Kovalchuk LV, Ivanyshyn IM. Features of psychological characteristics of adolescents with different levels of motor activity and different sports specialization. Naukovyi chasopys Natsionalnoho pedahohichnoho universytety imeni M. P. Drahomanova. 2017;5K(86):128-134.

11. Ihumnova OB. Individual and personal characteristics of students with negative mental states. Bulletin of the National Academy of the State Border Guard Service of Ukraine. Available: http://nbuv.gov.ua/UJRN/Vnadps_2012_5_38

12. Kominko SB, Kucher HV. Best psychodiagnosis methods: teaching guide. Ternopil: Kartblansh; 2005. $406 \mathrm{p}$.

13. Martynova NP. New types of aerobics as means for development of motor capacities of higher education institution students. Slobozhanskyi naukovo-sport. visnyk. 2014;1(39):62-65.

14. Pichurin VV. Features of association between physical fitness and student psychophysical characteristics. Naukovyi chasopys. Series: Naukovo-pedahohichni problem fizkultury. Fizkultura i sport. 2017;3K(84)17:365-68.

15. Rodin II. The problem of human psychomotor skills in the light of the scientific paradigm. Psychology. Historical and critical reviews and modern research. 2017;6(5A):5-23.

16. Semenova N, Mahliovanyi A. Motor activity and psychoemotional state of female students aged 15-17. Physical education, sport and health culture in modern society. 2015;2(30):95-98.

17. Serhiienko VM. Theoretico-methodical bases of motor capacity control in student youth during physical education [author's abstract]. Kyiv. 2016. $46 \mathrm{p}$.

18. Acevedo Edmund. Exercise Psychology: Understanding the Mental Health Benefits of Physical Activity and the Public Health Challenges of Inactivity. The Oxford Handbook of Exercise Psychology; 2012. DOI: 10.1093/oxford hb/9780195394313.013.0001.

19. Biddle S. Physical activity and mental health: evidence is growing. World Psychiatry. 2016;15(2):176-77. DOl: 10.1002/wps.20331.

20. Grasdalsmoen M, Eriksen HR, Lønning KJ, Sivertsen B. Physical exercise, mental health problems, and suicide attempts in university students. BMC Psychiatry. 2020 Apr 16;20(1):175. DOl: 10.1186/s12888-020-02583-3.

21. Khlopetskyi V, Kuryliuk S. Correction of students negative states by health fitness means as a scientific problem. Journal of Education, Health and Sport. 2017. 7 (2):859-70. eISSN 2391-8306. DOI: http:.dx.doi.org/10.5281/zenodo.3879686.

22. Lubans D, Richards J, Hillman C, Faulkner G, Beauchamp M, Nilsson M. et al. Physical activity for cognitive and mental health in youth: a systematic review of mechanisms. Pediatrics. 2016; 138(3): e20161642. DOI: 10.1542/peds.20161642.

23. Newell J, Aitchison T, Grant St. Statistics for Sports and Exercise Science: A Practical Approach. 1st Edition. Routledge; 1st edition (October 7, 2009); $440 \mathrm{p}$.

24. Thompson W. Worldwide survey of fitness trends for 2019. ACSM's Health \& Fitness Journal. 2018;22:10-17. DOI: 10.1249/ FIT.0000000000000438. 